\title{
Pengaruh Aktivitas Organisasi dan Intensitas Belajar Mahasiswa Pendidikan Matematika Terhadap Prestasi Belajar
}

\author{
Ari Suningsih ${ }^{1}$, Imam Nurohim ${ }^{2}$, Windi Ria Astuti ${ }^{3}$ \\ ${ }^{1,2,3}$ Pendidikan Matematika, Universitas Muhammadiyah Pringsewu, Indonesia \\ *ari.suningsih@umpri.ac.id
}

\begin{abstract}
Abstrak
Penelitian bertujuan untuk mengetahui pengaruh aktivitas mengikuti organisasi himpunan mahasiswa eksakta (HIMEKS) dan intensitas belajar terhadap prestasi belajar mahasiswa pendidikan matematika FKIP-UMPRI. Aktivitas yang dimaksud adalah keterlibatan dan peran penting dalam kegiatan di organisasi, guna membina dan mengembangkan bakat serta menambah motivasi mahasiswa. Intensitas belajar mencangkup motivasi, waktu atau durasi, kedisiplinan, konsentrasi, frekuensi, aktivitas dan presentasi. Jenis penelitian expost facto dengan pendekatan kuantitatif. Populasinya seluruh mahasiswa pendidikan matematika FKIP-UMPRI. Sampel penelitian adalah pengurus Himeks yang diambil menggunakan teknik purposive sampling yang berjumlah 43 orang. Pengumpulan data melalui penyebaran angket dan dokumentasi. Teknik analisis data menggunakan teknik analisis regresi sederhana dan analisis regresi ganda. Hasil analisis data : (1) terdapat pengaruh aktivitas mengikuti organisasi HIMEKS dengan sumbangsih sebesar $9,1 \%$ terhadap prestasi belajar mahasiswa. Pengaruh positif dengan koefisien korelasi $\left(\mathrm{r}_{\mathrm{x} 1 \mathrm{y}}\right)$ sebesar 0,302 dengan kategori rendah; (2) terdapat pengaruh intensitas belajar terhadap prestasi belajar mahasiswa dengan sumbangsih sebesar $28,7 \%$. Pengaruh positif ditunjukan dengan koefisien korelasi $\left(\mathrm{r}_{\mathrm{x} 2 \mathrm{y}}\right)$ sebesar 0,536 termasuk dengan kategori sedang.; (3) terdapat pengaruh aktivitas mengikuti organisasi HIMEKS dan intensitas belajar secara bersama-sama terhadap prestasi belajar mahasiswa sebesar 32,0\%. Pengaruh positif dengan koefisien korelasi sebesar $r_{\mathrm{x} 1 \mathrm{x} 2 \mathrm{y}}=0.566$ dalam kategori sedang.
\end{abstract}

Kata kunci: Aktivitas Organisasi; Intensitas; Prestasi Belajar.

\begin{abstract}
The study aimed to determine the effect of participating in the exact student association organization (HIMEKS) and the intensity of learning on student achievement in mathematics education at FKIP-UMPRI. The activity in question was the involvement and an essential role in the organization's activities to foster and develop talents and increase student motivation. The intensity of learning included motivation, time or duration, discipline, concentration, frequency, activity, and presentation. This type of research used ex post facto with a quantitative approach. The population was all students of mathematics education FKIP-UMPRI. The research sample was Himeks administrators who were taken using a purposive sampling technique, totaling 43 people. Data collection through the distribution of questionnaires and documentation. The data analysis technique used simple regression analysis technique and multiple regression analysis. The results of data analysis: (1) there was an effect of activities following the HIMEKS organization with a contribution of $9.1 \%$ on student learning achievement. A positive effect with a correlation coefficient ( $\left.r_{-} \times 1 y\right)$ of 0.302 with a low category; (2) there was an effect of learning intensity on student achievement with a contribution of $28.7 \%$. The positive effect showed by the correlation coefficient ( $\left.\mathrm{r}_{-} \mathrm{x} 2 \mathrm{y}\right)$ of 0.536 , including the medium category; (3) there was an effect of participating in the HIMEKS organization and the intensity of learning together on student learning achievement $32.0 \%$. A positive effect with a correlation coefficient of r_ $x 1 x 2 y=0.566$ in the medium category.
\end{abstract}

Keywords: Organizational Activities; Intensity; Learning Achievement.

Received: Maret 29, 2021/ Accepted: Juni 28, 2021/ Published Online: Juli 29, 2021 


\section{PENDAHULUAN}

Himpunan mahasiswa eksakta (HIMEKS) merupakan organisasi kemahasiswaan bagi mahasiswa program studi pendidikan matematika FKIP Universitas Muhammadiyah Pringsewu (UMPRI) Lampung. Organisasi kemahasiswaan adalah jalan untuk mahasiswa mengembangkan potensi yang ada dalam dirinya (Puspita, Andryana, \& Sari, 2020). Tidak hanya potensi non akademik tetapi juga bisa prestasi akademik. Mahasiswa yang aktif mengikuti kegiatan kemahasiswaan memiliki Indeks Prestasi Kumulatif (IPK) lebih baik dari pada mahasiswa yang tidak aktif mengikuti kegiatan kemahasiswaan. Bagi mahasiswa yang aktif dalam kegiatan kemahasiswaan, kegiatan kemahasiswaan menjadi sebuah tantangan (Febriana, Winanti, \& Amelia, 2013). Tantangannya adalah bagaimana cara mahasiswa membagi waktu yang baik dalam kegiatan kemahasiswaan dan kegiatan perkuliahan. Kegiatankemahasiswaan dapat dilakukan melalui suatu organisasi kemahasiswaan yang ada di Perguruan Tinggi. Sudah jelas bahwa setiap (Saepudin, 2011). Adanya organisasi-organisasi kemahasiswaan tidak hanya untuk kepentingan mahasiswa semata, tetapi juga kepentingan bagi perguruan tinggi (Rahayu, 2018), hal itu karena adanya (Suartini \& Sukandar, 2016).

Berdasarkan pengamatan yang dilakukan kepada beberapa mahasiswa yang mengikuti organisasi HIMEKS. Penulis menemukan beberapa permasalahan yang dihadapi oleh mahasiswa. Permasalahan tersebut yaitu sebagian mahasiswa yang mengikuti organisasi HIMEKS memiliki prestasi belajar kurang bagus. Hal itu terjadi karena alasan mahasiswa yang mengikuti Organisasi HIMEKS kesulitan dalam membagi waktu antara kegiatan organisasi dengan kegiatan belajar atau akademis. Faktor lain yang mempengaruhi prestasi belajar mahasiswa yang aktif dalam mengikuti organisasi HIMEKS yaitu intensitas belajar (Novitasari, 2016). Mahasiswa yang mengalami kesulitan membagi jam belajar bisa mempengaruhi prestasi mahasiswa yang aktif dalam berorganisasi. Mahasiswa yang ikut dan tidak ikut dalam organisasi tidak semuanya mendapatkan prestasi belajar yang baik dan tidak semuanya juga mahasiswa yang ikut dalam organisasi dan tidak ikut dalam organisasi memperoleh prestasi yang kurang baik. Atas hal tersebut, sehingga perlu adanya penelitian dengan tujuanuntuk mengatahui pengaruh aktivitas mengikuti organisasi HIMEKS dan intensitas belajar terhadap prestasi belajar mahasiswa program studi pendidikan matematika di FKIP-UMPRI.

Dalam kamus besar bahasa Indonesia, aktivitas diartikan sebagai segala sesuatu bentuk keaktifan dan kegiatan. Aktivitas adalah kekaktifan, kegiatan-kegiatan, kesibukan atau bisa juga berarti kerja atau salah satu kegiatan kerja yang dilaksanakan tiap bagian dalam tiap suatu organisasi atau lembaga. (Astuti, Hadiwinarto, \& Sholihah, 2018). Aktivitas ini dilakukan 
bukan pada saat jam perkuliahan melainkan di luar jam atau bangku perkuliahan. Aktivitasaktivitas tersebut dapat berupa aktif dalaam organisasi internal maupun eksternal kampus. Menurut Baswedan dalam (Hakim, Wahyudi, \& Thomas, 2016) aktivitas organisasi dapat meningkatkan soft skill mahasiswa, terutama kompetensi leadership dan kemampuan berkomunikasi. Selain itu manfaat mahasiswa dalam mengikuti organisasi adalah sebagai wadah untuk aktualisasi diri (Febriana, Winanti, \& Amelia, 2013).

Sejalan dengan pendapat dari (Suherman, 2017) yang mengatakan bahwa ketika mengikuti organisasi akan ada manfaat yang bisa dipetik, (Pinatih \& Vembriati, 2019), mengupgrade dan mengembangkan potensi diri (soft skills), mengembangkan minat dan bakat, melatih manajemen waktu, memperluas jaringan, dan melatih leadership serta menumbuhkan motivasi. Berdasarkan penelitian sebelumnya oleh Sholikhah__(2018) mahasiswa yang aktif dalam organisasi di lingkup universitas tetap mendapatkan prestasi belajar dengan kategori sangat memuskan. Sehingga keaktifan mahasiswa dalam organisasi berpengaruh positif terhadap prestasi belajar serta aktivitas mahasiswa berorganisasi merupakan salah satu faktor eksternal yang mempengaruhi prestasi belajar.

Aktivitas mahasiswa dalam berorganisasi terkadang membuat mahasiswa kesulitas dalam mengatur waktu antara kegiatan akademik dan esktra akademik. Hal tersebut membuat intensitas belajar mahasiswa terkait dengan materi perkuliahan menjadi terganggu (Lestari, Ma'wiyah, \& Ihsan, 2020). Menurut intensitas belajar adalah realitas dari motivasi dalam rangka mencapai tujuan yang diharapkan yaitu peningkatan prestasi, sebab seseorang melakukan usaha dengan penuh semangat karena adanya motivasi sebagai pendorong pencapaian (Lestari, Ma'wiyah, \& Ihsan, 2020). Dari pengertian tersebut intensitas belajar bagi mahasiswa perlu diperhatikan demi mendorong tercapainya hasil belajar yang baik bagi mahasiswa. Berdasarkan penelitian sebelunya oleh (Lestari, Ma'wiyah, \& Ihsan, 2020) salah satu faktor yang mempengaruh prestasi belajar mahasiswa adalah intensitas belajar mahasiswa itu sendiri. Intensitas belajar (intensity) meliputi banyak aspek antara lain durasi, frekuensi, aktivitas dan presentasi atau target (Sumadji, 2017).

Berdasarkan apa yang telah diuraikan, maka tujuan dari penelitian ini yaitu untuk mengetahui pengaruh aktivitas mengikuti organisasi Himpunan Mahasiswa Eksakta (HIMEKS) terhadap prestasi belajar mahasiswa Program Studi Pendidikan Matematika FKIP-UMPRI, mengetahui pengaruh intensitas belajar terhadap prestasi belajar mahasiswa Program Studi Pendidikan Matematika FKIP-UMPRI, mengetahui pengaruh aktivitas mengikuti organisasi 
Himpunan Mahasiswa Eksakta (HIMEKS) dan intensitas belajar terhadap prestasi belajar mahasiswa Program Studi Pendidikan Matematika FKIP-UMRI.

\section{METODE}

Penelitian yang dilakukan menggunakan pendekatan kuantitatif dimana kuantitatif berarti berkaitan dengan angka-angka. Maksudnya data yang diperoleh dari pendekatan kuantitatif adalah data yang berupa angka-angka. Hal itu sejalan dengan pendapat (Sugiyono, 2011) yang mengatakan bahwa penelitian kuantitatif merupakan penelitian dengan data yang didapat berupa angka-angka dan analisisnya menggunakan statistik. Dalam penelitian terdapat tiga variabel yang terdiri dari dua variabel bebas dan satu variabel terikat. Variabel bebas dalam penelitian ini adalah aktivitas mahasiswa dalam mengikuti organisasi HIMEKS $\left(X_{1}\right)$ dan intensitas belajar yang diberi symbol $\left(X_{2}\right)$.Variabel terikat dalam penelitian ini adalah prestasi belajar mahasiswa yang diberi simbol $Y$. Analisis data dalam penelitian dilakukan dengan bantuan program microsoft excel 2007 dan SPSS Statistic 23.

Populasi dalam penelitian adalah anggota pengurus organisasi HIMEKS, dimana anggota HIMEKS merupakan seluruh mahasiswa pendidikan matematika FKIP-UMPRI. Dengan teknik sampling purposive maka sampel dalam penelitian ini adalah anggota pengurus di organisasi HIMEKS 2020/2021 yang berjumlah 43 mahasiswa. Analisis data menggunakan analisis analisis regresi sederhana untuk hipotesis pertama dan kedua. Hipotesis pertama berbunyi terdapat pengaruh positif dan signifikan antara aktivitas mengikuti organisasi HIMEKS terhadap prestasi belajar mahasiswa pendidikan matemaika. Hipotesis kedua berbunyi terdapat pengaruh positif dan signifikan antara intensitas belajar terhadap prestasi belajar mahasiswa pendidikan matematika.Serta analisis regresi ganda untuk hipotesis ketiga yang berbunyi terdapat pengaruh aktivitas mengikuti organisasi HIMEKS dan intensitas belajar secara bersama-sama terhadap prestasi belajar mahasiswa pendidikan matematika. Teknik pengumpulan data adalah suatu cara khusus yang digunakan peneliti dalam menggali data yang diperlukan dalam penelitian. Adapun teknik yang digunakan dalam pengumpulan data adalah kuosioner dan dokumentasi.

\section{HASIL PENELITIAN}

Analisis data dalam penelitian dilakukan dengan bantuan program microsoft excel 2007 dan SPSS Statistic 23. Ringkasan hasil analisis pada hipotesis pertama ditunjukan pada Tabel 1 sebagai berikut: 
Tabel 1. Ringkasan hasil uji hipotesis pertama

\begin{tabular}{llcccl}
\hline No & Pers. Regresi & $\boldsymbol{r}_{\boldsymbol{x 1 y}}$ & $\boldsymbol{r}_{\boldsymbol{x 1 \boldsymbol { y }}}^{\mathbf{2}}$ & $\boldsymbol{F}_{\text {hitung }}$ & Ket. \\
\hline$X_{1}$ terhadap $Y$ & $\hat{Y}=78.590+0.148 X_{1}$ & 0.302 & 0,091 & 4.118 & Rendah \\
\hline
\end{tabular}

a. Persamaan Regresi

Berdasarkan hasil analisis maka persamaan regresi dinyatakan sebagai berikut : $\widehat{Y}=78.590+0.148 X_{1}$.

b. Koefisien Korelasi $\left(r_{x 1 y}\right)$

Berdasarkan analisis dapat diketahui bahwa nilai koefisien korelasi $\left(r_{x 1 y}\right)$ aktivitas mengikuti organisasi HIMEKS sebesar 0,302. Hubungan tersebut berdasarkan interpretasi pada $\underline{\text { Tabel } 2}$ berada pada tingkatan rendah.

Tabel 2. Interpretasi koefisien korelasi

\begin{tabular}{cc}
\hline Interval koefisien & Tingkat Hubungan \\
\hline $0.00-0.199$ & Sangat Rendah \\
$0.20-0.399$ & Rendah \\
$0.40-0.599$ & Sedang \\
$0.60-0.799$ & Kuat \\
$0.80-1.000$ & Sangat Kuat \\
\hline
\end{tabular}

c. Koefisien Determinasi

Nilai koefisien determinasi $\left(r_{x 1 y}^{2}\right)$ sebesar 0,091 atau 9,1\%, yang memiliki maksut bahwa perubahan yang terjadi pada prestasi belajar mahasiswa dipengaruhi oleh aktivitas mahasiswa dalam mengikuti organisasi HIMEKS dengan sumbangsih sebesar 9,1\% . Sisanya dipengaruhi faktor lain.

d. Signifikansi

Hasil analisis didapat $F_{\text {hitung }}=4.118$ selanjutnya dibandingkan dengan $F_{\text {tabel }}$ untuk taraf signifikan 5\%. Maka didapat $F_{\text {tabel }}=4.08$. Karena $F_{\text {hitung }} \geq F_{\text {tabel }}(4.118 \geq 4.08)$, maka dapat disimpulkan terdapat pengaruh signifikan antara aktivitas mengikuti organisasi HIMEKS terhadap prestasi belajar mahasiswa program studi pendidikan matematika FKIPUMPRI. Selanjutnya ringkasan hasil analisis data untuk hipotesis kedua, ditunjukan pada $\underline{\text { Tabel } 3}$ sebagai berikut:

Tabel 3. Ringkasan hasil uji hipotesis Kedua

\begin{tabular}{lcccl}
\hline No & Pers. Regresi & $\boldsymbol{r}_{\boldsymbol{x} \mathbf{y} \boldsymbol{y}}$ & $\boldsymbol{r}_{\boldsymbol{x} \mathbf{2} \boldsymbol{y}}$ & $\boldsymbol{F}_{\boldsymbol{h i t u n}}$ Ket. \\
\hline$X_{2}$ terhadap $Y$ & $\hat{Y}=73.839+0.220 X_{2}$ & 0.536 & 0,287 & 9,780 Sedang \\
\hline
\end{tabular}


a. Persamaan Regresi

Berdasarkan hasil analisis maka persamaan regresi dinyatakan sebagai berikut : $\widehat{Y}=73.839+0.220 X_{2}$.

b. Koefisien Korelasi $\left(r_{x 2 y}\right)$

Nilai koefisien korelasi $\left(r_{x 2 y}\right)$ intensitas belajar sebesar 0,536. Nilai tersebut merupakan angka positif yang berarti bahwa intensitas belajar memiliki hubungan yang positif terhadap prestasi belajar mahasiswa. Hubungan tersebut berdasarkan interpretasi berada pada tingkatan sedang.

c. Koefisien Determinasi

Nilai koefisien determinasi $\left(r^{2}{ }_{x 2 y}\right)$ sebesar 0,287 atau 28,7\%, yang memiliki maksut bahwa perubahan yang terjadi pada prestasi belajar mahasiswa dipengaruhi oleh intensitas belajar dengan sumbangsih sebesar 28,7\%. Sisanya dipengaruhi faktor lain.

d. Signifikansi

Hasil analisis didapat $F_{\text {hitung }}=9,780$ selanjutnya dibandingkan dengan $F_{\text {tabel }}$ untuk taraf signifikan 5\%. Maka didapat $F_{\text {tabel }}=4.08$. Karena $F_{\text {hitung }} \geq F_{\text {tabel }}(9,780 \geq 4.08)$, maka dapat disimpulkan terdapat pengaruh signifikan antara intensitas belajar terhadap prestasi belajar mahasiswa program studi pendidikan matematika FKIP-UMPRI

Kemudian raingkasan hasil analisis data untuk hipotesis ketiga dapat dilihat pada Tabel 4 di bawah ini:

Tabel 4. Ringkasan hasil uji hipotesis Ketiga

\begin{tabular}{llllll}
\hline No & Persamaan Regresi Ganda & $\boldsymbol{r}_{\boldsymbol{x} 1 \boldsymbol{y}}$ & $\boldsymbol{r}^{2}{ }_{\boldsymbol{x} 1 \boldsymbol{y}}$ & $\boldsymbol{F}_{\text {hitung }}$ & Ket. \\
\hline$X_{1}$ dan $_{2}$ terhadap $Y$ & $\hat{Y}=69.933+0.091 X_{1}+0.202 X_{2}$ & 0.566 & 0,320 & 9.415 & Sedang \\
\hline
\end{tabular}

a. Persamaan Regresi

Hasil analisis menghasilkan persamaan regresi ganda $\widehat{Y}=69.933+0.091 X_{1}+0.202 X_{2}$.

b. Koefisien Korelasi $\left(r_{x 1 x 2 y}\right)$

Nilai koefisien korelasi $\left(r_{x 1 x 2 y}\right)$ intensitas belajar sebesar 0,566. Hubungan tersebut berdasarkan interpretasi berada pada tingkatan sedang.

c. Koefisien Determinasi

Nilai koefisien determinasi $\left(r_{x 1 \times 2 y}^{2}\right)$ sebesar 0,320 atau 32,0\%, yang memiliki maksut bahwa perubahan yang terjadi pada prestasi belajar mahasiswa dipengaruhi secara bersamasama oleh aktivitas mengikuti organisasi HIMEKS dan intensitas belajar dengan sumbangsih sebesar 32,0\%. Sisanya dipengaruhi faktor lain. 


\section{d. Signifikansi}

Hasil analisis didapat $F_{\text {hitung }}=9,415$ selanjutnya dibandingkan dengan $F_{\text {tabel }}$ untuk taraf signifikan 5\%. Maka didapat $F_{\text {tabel }}=4.08$. Karena $F_{\text {hitung }} \geq F_{\text {tabel }}(9,415 \geq 4.08)$, maka dapat disimpulkan terdapat pengaruh yang signifikan aktivitas mengikuti organisasi HIMEKS dan intensitas belajar secara bersama-sama terhadap prestasi belajar mahasiswa program studi pendidikan matematika FKIP-UMPRI

\section{PEMBAHASAN}

Pengaruh dari aktivitas mengikuti organisasi HIMEKS terhadap prestasi belajar dapat dilihat dari persamaan regresi $\hat{Y}=78.590+0.148 X_{1}$ yang menunjukan bahwa koefisien regresi untuk variabel aktvitas mengikuti organisasi HIMEKS sebesar 0,148, artinya aktivitas mahasiswa dalam mengikuti organisasi himpunan mahasiswa eksakta (HIMEKS) berpengaruh terhadap prestasi belajarnya. Jika variabel aktivitas mengikuti organisasi ditingkatkan maka akan diikuti dengan meningkatnya prestasi belajar mahasiswa. hal ini menunjukan bahwa semakin tinggi aktivitas mahasiswa dalam berorganisasi HIMEKS makan akan semakin baik prestasi belajarnya. Kemudian dilakukan uji $F$ diperoleh $F_{\text {hitung }}=4,118$ yang selanjutnya dibandingkan dengan $F_{\text {tabel }}$ untuk $a=0,05$ didapat $F_{\text {tabel }}=4,84$. Dengan kriteria uji jika $F_{\text {hitung }}>F_{\text {tabel }}$ maka tolak $H_{0}$ dan jika $F_{\text {hitung }} \leq F_{\text {tabel }}$ maka terima $H_{0}$, karena $F_{\text {hitung }}>$ $F_{\text {tabel }}$ maka tolak $H_{0}$ berarti terima $H_{1}$. Maka dapat disimpulkan bahwa ada pengaruh yang signifikan antara aktivitas mengikuti organisasi HIMEKS terhadap prestasi belajar mahasiswa. Hal ini sesuai dengan hipotesis peneliti.

Setelah analisis tersebut, kemudian dilanjutkan dengan mencari korelasi. Analisis korelasi dilakukan untuk mengetahui seberapa besar tingkat pengaruh variabel bebas $(\mathrm{X})$ terhadap variabel terikat (Y). Nilai koefisien korelasi yang diperoleh antara aktivitas mengikuti organisasi HIMEKS terhadap prestasi belajar mahasiswa adalah 0,302. Hal ini menunjukan, bahwa hubungan antara aktivitas mengikuti organisasi HIMEKS terhadap prestasi belajar mahasiswa memiliki hubungan yang rendah. Besarnya persentase sumbangan pengaruh aktivitas mengikuti organisasi HIMEKS terhadap prestasi belajar mahasiswa dapat diketahui dari koefisien determinasi $\left(r^{2}\right)$ yaitu 0,091 atau 9,1\% sedangkan sisanya dipengaruhi oleh factor lain. Hasil tersebut juga mengandung arti bahwa aktivitas mahasiswa dalam mengikuti organisasi (HIMEKS) memiliki pengaruh positif terhadap prestasi belajar mahasiswa. 
Aktivitas mahasiswa dalam mengikuti organisasi HIMEKS yang dimaksud dalam penelitian ini adalah keterlibatan dan berperan penting dalam kegiatan-kegiatan yang diadakan organisasi tersebut guna membina dan mengembangkan minat dan bakat serta menambah wawasan mahasiswa dengan harapan membawa prestasi seperti berprestasi dalam bidang akademik. Hal ini dilakukan karena HIMEKS merupakan sebuah wadah atau sarana bagi anggotanya selaku mahasiswa untuk menambah wawasan ilmu pengatahuan baik dari segi akademis maupun sosial sehingga dapat membantu dalam meningkatkan prestasi belajar mahasiswanya serta kemampuan dalam bersosialisasi di lingkungan baik kampus maupun luar kampus.

Dalam penelitian ini juga bermaksud memberikan pemahaman kepada mahasiswa pendidikan matematika, dimana mahasiswa matematika harus sadar bahwa organisasi HIMEKS merupakan organisasi di bawah naungan program studi pendidikan matematika. Oleh sebab itu tidak seharusnya organisasi mahasiswa tingkat jurusan memberikan dampak negatif bagi mahasiswa pada kegiatan akademik mahasiswa selaku anggotanya, bahkan sebaliknya seharusnya organisasi HIMEKS memberikan dampak positif bagi kegiatan akademik serta prestasi mahasiswa pendidikan matematika. Terbukti dari hasil penelitian bahwa aktivitas mahasiswa dalam mengikuti organisasi HIMEKS memberikan dampak positif bagi mahasiswa pendiidkan matematika.

Hasil penelitian ini relevan dengan penelitian yang dilakukan oleh (Haryono, Akhdinirwanto, \& Ashari, 2014) bahwa keaktifan mahasiswa dalam berorganisasi memberikan faktor yang positif dalam meningkatkan prestasi belajar. Mahasiswa yang aktif dalam organisasi yang ada di lingkup universitas tetap memiliki prestasi belajar yang sangat memuaskan (Shaleh, 2016). Tidak dapat dipungkiri, memang setiap aktivitas yang dilakukan oleh mahasiswa dalam berorganisasi menimbulkan dampak atau efek. Dampak yang bisa dirasakan dari berorganisasi diantaranya yaitu kemampuan mengatur waktu, kedewasaan dalam bersikap dan kemampuan komunikasi yang menjadi lebih baik, sikap kreatif dan inofatif, serta melatih mahasiswa dalam bernalar atau berfikir kritis (Suwena \& Meitriana, 2018). Menurut hasil penelitian (Pradayu, 2017) bahwa dampak yang bisa dirasakan ketika mahasiswa mengikuti organisasi adalah perubahan sikap atau tingkah laku, timbul semangat juang yang diberikan oleh teman, jiwa kompetisi dalam meraih prestasi serta kepribadian yang mendorong mahasiswa bersifat dewasa akibat pergaulan yang ditimbulkan oleh teman organisasi dalam menghadapi setiap tantangan dalam menjalankan aktivitas yang dilaksanakan. 
Dari dampak yang diperoleh ketika mahasiswa mengikuti organisasi, itu bisa dijadikan dorongan berprestasi agar memperoleh prestasi belajar yang baik. Karena untuk membangkitkan dorongan berprestasi beberapa hal yang diperlukan menurut (Surya, 2011) adalah mengembangkan ketajamn bernalar atau berfikir kritis, mengembangkan jiwa petarung atau kompetisi, mengembangkan sikap kreatif dan inofatif serta mengembangkan semangat juang. Berdarkan penelitian yang relevan dan kajian teori semakin memperkuat hasil penelitian bahwa aktivitas mahasiswa dalam mengikuti organisasi HIMEKS berpengarauh positif terhadap prestasi belajar mahasiswa pendidikan matematika FKIP-UMPRI.

Pengaruh intensitas belajar terhadap prestasi belajar mahasiswa terlihat dari persamaan $\widehat{Y}=73.839+0.220 X_{2}$ yang artinya jika skor intensitas belajaar $\left(X_{2}\right)$ mengalami peningkatan 1 poin, maka nilai prestasi belajar mahasiswa akan meningkat sebesar 0,220. Maka dapat disimpulkan bahwa ada pengaruh yang signifikan antara intensitas belajar terhadap prestasi belajar mahasiswa. Hal ini sesuai dengan hipotesis peneliti.

Setelah analisis tersebut, kemudian dilanjutkan dengan mencari korelasi. Analisis korelasi dilakukan untuk mengetahui seberapa besar tingkat pengaruh antara variabel bebas $(\mathrm{X})$ terhadap variabel terikat (Y). Nilai koefisien korelasi yang diperoleh antara aktivitas mengikuti organisasi HIMEKS terhadap prestasi belajar mahasiswa adalah 0,536. Hal ini menunjukan, bahwa hubungan antara intensitas belajar mahasiswa terhadap prestasi belajar mahasiswa memiliki hubungan yang sedang. Besarnya persentase sumbangan intensitas belajar terhadap prestasi belajar mahasiswa dapat diketahui dari koefisien determinasi $\left(r^{2}\right)$ yaitu 0,287 atau 28,7\% sedangkan sisanya dipengaruhi oleh factor lain. Hasil tersebut juga mengandung arti bahwa intensitas belajar memiliki pengaruh positif terhadap prestasi belajar mahasiswa program studi pendidikan matematika FKIP-UMPRI.

Intensitas belajar merupakan ukuran atau kedisiplinan waktu dalam belajar untuk memperoleh pengetahuan, keterampilan serta pemahaman baru yang dilakukan dengan penuh semangat karena adanya motivasi. Menurut (Sumadji, 2017) intensitas belajar (intensity) meliputi banyak aspek antara lain durasi, frekuensi, aktivitas dan presentasi (target, cita-cita). Intensitas belajar penting dilakukan mengingat tanpa adanya usaha atau rutinitas belajar yang memadai seseorang menjadi kurang teratur dan cepat bosan dalam kegiatan belajar (Purmadi, 2013). Selain itu juga, intensitas belajar sangat menentukan tingkat pencapaian tujuan belajar yakni meningkatkan prestasi belajar (Effendi, Mursilah, \& Mujiono, 2018). Hasil penelitian ini relevan dengan penelitian sebelumnya yang dilakukan oleh (Lestari, Ma'wiyah, \& Ihsan, 2020) yang menyatakan bahwa intensitas belajar berpengaruh langsung terhadap IPK mahasiswa. 
Berdasarkan beberapa pendapat dan hasil penelitiaa yang relevan, hal ini lebih menguatkan hasil penelitian yang sudah penulis lakukan yaitu, memang benar bahwa intensitas belajar yang dilakukan oleh mahasiswa itu mempengaruhi prestasi belajarnya. Dari hasil penelitian intensitas belajar mahasiswa memliki pengaruh positif terhadap prestasi belajar mahasiswa pendidikan matematika. Semakin tinggi intensitas belajar yang dilakukan oleh mahasiswa maka prestasi belajarnya pun akan semakin baik atau bagus.

Pengaruh aktivitas mahasiswa dalam mengikuti organisasi HIMEKS dan intensitas belajar secara bersama-sama terhadap prestasi belajar mahasiswa program studi pendidikan matematika FKIP-UMPRI terlihat dari persamaan $\hat{Y}=69.933+0.091 X_{1}+0.202 X_{2}$ yang artinya terdapat pengaruh positif aktivitas mahasiswa dalam mengikuti organisasi HIMEKS dan intensitas belajar secara bersama-sama terhadap prestaasi belajar mahasiswa. Nilai koefisien regresi variabel aktivitas mahasiswa dalam mengikuti organisasi $\left(X_{1}\right)$ sebesar 0,091. Apabila nilai aktivitas mahasiswa dalam mengikuti organisasi HIMEKS $\left(X_{1}\right)$ mengalami peningkatan 1 poin, maka nilai prestasi belajar mahasiswa akan meningkat sebesar 0,091 dengan asumsi bahwa variabel intensitas belajar $\left(X_{2}\right)$ dalam kondisi tetap. Nilai koefisien regresi variabel intensitas belajar $\left(X_{2}\right)$ sebesar 0,202. Apabila nilai intensitas belajar $\left(X_{2}\right)$ mengalami peningkatan 1 poin, maka nilai akan meningkat sebesar 0,202, dengan asumsi bahwa variabel aktivitas mahasiswa dalam mengikuti organisasi dalam kondisi tetap. Maka dapat disimpulkan bahwa ada pengaruh yang signifikan antara aktivitas mengikuti organisasi HIMEKS dan intensitas belajar secara bersama-sama terhadap prestasi belajar mahasiswa program studi pendidikan matematika FKIP-UMPRI. Hal ini sesuai dengan hipotesis peneliti.

Setelah analisis tersebut, kemudian dilanjutkan dengan mencari korelasi. Analisis korelasi dilakukan untuk mengetahui seberapa besar tingkat pengaruhnya. Nilai koefisien korelasi yang diperoleh adalah 0,566. Hal ini menunjukan, bahwa hubungan antara intensitas belajar mahasiswa terhadap prestasi belajar mahasiswa memiliki hubungan yang sedang. Besarnya persentase sumbangan intensitas belajar terhadap prestasi belajar mahasiswa dapat diketahui dari koefisien determinasi $\left(r^{2}\right)$ yaitu 0,320 atau $32,0 \%$ sedangkan sisanya dipengaruhi oleh factor lain. Hasil tersebut juga mengandung arti bahwa aktivitas mengikuti organisasi HIMEKS dan intensitas belajar secara bersama-sama memiliki pengaruh positif terhadap prestasi belajar mahasiswa program studi pendidikan matematika FKIP-UMPRI. 


\section{SIMPULAN}

Berdasarkan hasil analisis data dan pembahasan, maka penulis menarik kesimpulan bahwa memang terdapat pengaruh positif dan signifikan antara aktivitas mengikti organisasi HIMEKS dan intensitas belajar terhadap prestasi belajar mahasiswa program studi pendidikan matematika FKIP-UMPRI. Ketika aktivitas mahasiswa dalam mengikuti organisasi HIMEKS meningkat hal itu dapat membuat prestasi belajar mahasiswa pendidikan matematika menjadi lebih baik. Ha itu karena dampak yang diperoleh ketika mahasiswa mengikuti organisasi, salah satunya meningkatkan motivasi dalam diri. Kemudian intensitas belajar mahasiswa juga memiliki pengaruh terhadap prestasi belajar mahasiswa semakin tinggi intensitas belajar mahasiswa maka akan semakin baik pula prestasi belajar mahasiswa hal iitu karena berdasarkan analisis data terdapat pengaruh yang positif dan signifikan antara intensitas belajar terhadap prestasi belajar mahasiswa pendidikan matematika FKIP-UMPRI.

\section{REFERENSI}

Astuti, P. D., Hadiwinarto, H., \& Sholihah, A. (2018). Studi Deskriptif Interaksi Sosial Mahasiswa S1 Jurusan Ilmu Pendidikan Berdasarkan Keterlibatan Organisasi Kemahasiswaan Di Fakultas Keguruan Dan Ilmu Pendidikan Universitas Bengkulu. Consilia: Jurnal Ilmiah Bimbingan Dan Konseling, 1(2), 20-28. https://doi.org/10.33369/consilia.1.2.20-28

Effendi, E., Mursilah, M., \& Mujiono, M. (2018). Korelasi Tingkat Perhatian Orang Tua dan Kemandirian Belajar dengan Prestasi Belajar Siswa. Titian Ilmu: Jurnal Ilmiah Multi Sciences, 10(1), 17-23. https://doi.org/10.30599/jti.v10i1.131

Febriana, B., Winanti, L., \& Amelia, S. (2013). Hubungan Antara Keaktifan Organisasi dengan Prestasi Belajar (Indeks Prestasi) Mahasiswa Fakultas Ilmu Keperawatan Universitas Indonesia. Prosiding Konferensi Nasional PPNI Jawa Tengah. (154-157). Sultan Agung Islamic University, Semarang.

Hakim, D. R., Wahyudin, A., \& Thomas, P. (2016). Peran soft skill dalam memediasi pengaruh prestasi belajar dan aktivitas berorganisasi terhadap daya saing mahasiswa pendidikan ekonomi universitas kuningan. Journal of Economic Education, 5(2), 154-167.

Haryono, E., Akhdinirwanto, R. W., \& Ashari, A. (2014). Pengaruh Keaktifan Berorganisasi dan Konsep Diri tehadap Indeks Prestasi Mahasiswa Program Studi Pendidikan Fisika Universitas Muhammadiyah Purworejo Tahun Akdemik 2013/2014. Radiasi: Jurnal Berkala Pendidikan Fisika, 4(1), 78-80.

Lestari, A., Ma’wiyah, N., \& Ihsan, M. (2020). Kontribusi Dukungan Keluarga dan Teman Bergaul Terhadap Indeks Prestasi Kumulatif Mahasiswa Dengan Memperhatikan Intensitas Belajar. Al-Khwarizmi: Jurnal Pendidikan Matematika Dan Ilmu Pengetahuan Alam, 8(1), 51-60. https://doi.org/10.24256/jpmipa.v8i1.1318 
Novitasari, N. A. (2016). Pengaruh intensitas belajar terhadap hasil belajar siswa kelas $V$ di SD gugus terampil kecamatan Secang kabupaten Magelang (Doctoral dissertation, Universitas Negeri Semarang).

Pinatih, G. A. R. A., \& Vembriati, N. (2019). Persepsi penggunaan gaya manajemen konflik oleh pemimpin terhadap kepuasan anggota di organisasi kemahasiswaan Universitas $\begin{array}{lllll}\text { Udayana. Jurnal } & \text { Psikologi Udayana, } & \text { 6(02), }\end{array}$ https://doi.org/10.24843/JPU.2019.v06.i02.p06

Pradayu, M. (2017). Pengaruh Aktivitas Organisasi Terhadap Prestasi Belajar. Jom Fisip, 4(2), $1-12$.

Purmadi, A. (2016). Hubungan intensitas belajar terhadap prestasi belajar fisika siswa SMA. Jurnal Teknologi Pendidikan: Jurnal Penelitian dan Pengembangan Pembelajaran, 1(2), 77-85.

Puspita, A. T., Andryana, S., \& Sari, R. T. K. (2020). Rancang Bangun Game Birokrasi Penyelenggaraan Kegiatan Kemahasiswaan Menggunakan Metode Finite State Machine. Jurnal ELTIKOM: Jurnal Teknik Elektro, Teknologi Informasi dan Komputer, 4(1), 39-47. https://doi.org/10.31961/eltikom.v4i1.141

Rahayu, N. L. G. B. (2018). Aplikasi Manajemen Jadwal Audiensi Organisasi Mahasiswa STIKOM Bali Menggunakan Framework Laravel. Denpasar: STIKOM Bali.

Saepudin, E. (2011). Model Pembelajaran Demokrasi Melalui Pengembangan Organisasi Kemahasiswaan (Studi Kasus Terhadap Organisasi Kemahasiswaan di Universitas Pendidikan Indonesia Bandung). Skripsi, Universitas Pendidikan Indonesia. Diambil dari http://a-research.upi.edu/skripsiview.php?no_skripsi=5152

Shaleh, M. (2016). Pengaruh Motivasi, Faktor Keluarga, Lingkungan Kampus Dan Aktif Berorganisasi Terhadap Prestasi Akademik. Phenomenon : Jurnal Pendidikan MIPA, 4(2), 109-141. https://doi.org/10.21580/phen.2014.4.2.122

Sholikhah, A. (2018). Pengaruh Keaktifan Mahasiswa Dalam Organisasi Terhadap Prestasi Belajar Mahasiswa Jurusan Pendidikan Ekonomi FE Unesa Angkatan 2015. Jurnal Pendidikan Ekonomi (JUPE), 6(2), 76-80.

Suartini, T., \& Sukandar, A. (2016). Pengaruh Organisasi Kemahasiswaan Terhadap Motivasi Belajarmahasiswa Dalam Menghadapi Era Globalisasi.

Sugiyono. (2011). Metode Penelitian Pendidikan Pendekatan Kuantitatif, Kualitatif, dan R\&D. Bandung: Alfabeta.

Suherman. (2017). Menjadi Mahasiswa Ideal Sukses Akademis dan Organisasi. Yogyakarta: UGM Press.

Sumadji. (2017). Kontribusi esai terhadap hasil belajar mahasiswa. Jurnal Inspirasi Pendidikan, 7(2), 155-163.

Surya, H. (2011). Strategi Jitu Mencapai Kesuksesan Belajar. Jakarta: PT Elex Media Komputindo.

Suwena, K. R., \& Meitriana, M. A. (2018). Organisasi Salah Satu Faktor Pendukung Prestasi Belajar Mahasiswa. Ekuitas: Jurnal Pendidikan Ekonomi, 6(2), 62-68. https://doi.org/10.23887/ekuitas.v6i2.16301 